\title{
THE EFFECT OF LEVERAGE, LEGISLATIVE SUPERVISION, AND FINANCIAL PERFORMANCE ON AUDIT FINDINGS AND GOVERNMENT REPORT LEVELS IN INDONESIA
}

\author{
Hartati Sri \\ Institut Pemerintahan Dalam Negeri, Indonesia \\ E-mail: srihartati@ipdn.ac.id
}

\begin{abstract}
This study aims to analyze the effect of leverage, legislative oversight, and financial performance on audit findings and reporting levels of local governments in Indonesia. The grand theories used in this research are stewardship theory and signaling theory. The population in this study was all-district and city governments in Indonesia. The sample was taken by purposive sampling to obtain a sample of 203 local governments. The data analysis method used in this research is Partial Least Square (PLS) analysis. The results of this study indicate those audit findings have an effect and are signed on the level of reporting of local governments in Indonesia. Financial performance has a significant and significant effect on audit findings. Financial performance does not affect and is significant on the level of local government reporting in Indonesia. Legislative oversight does not affect and is significant on audit findings in local governments. Legislative observers are influential and significant on the level of local government reporting in Indonesia. Leverage does not affect and is significant on audit findings. Leverage affects and is significant on the level of government reports.
\end{abstract}

\section{KEY WORDS}

Leverage, legislative oversight, financial performance, audit findings, report level.

In 2012, the government made an increase in the accountability of regional financial management by issuing the Minister of Home Affairs Instruction number 188.52 / 1797 / SJ regarding the transparency of regional budget management. This instruction mandates local governments to prepare a context menu with the name "Transparency in Regional Budget Management" on the official local government website and is obliged to publish 12 regional budget management documents to the public on the official website. The results of a survey conducted by the Indonesian Forum for Budget Transparency (FITRA) in 2013 revealed that the majority of LGs are still reluctant to publish budget management on their official website. Research conducted by Chusna (2016) found that out of 118 regional governments, only 24.5 percent disclosed complete budget management information on the websites of regions.

The ease of access to local government financial information is a reflection of stewardship theory. The relationship between the community (principal) and the government (stewards) is a relationship that is created because of the human nature that can be trusted, responsible, integrity, and honesty to other parties. Under the stewardship theory view, the government as a party that has more information, especially financial information, will strive to create transparency towards society (Nosihana and Yaya, 2016). The concept of signaling theory explains that the government as the party carrying out the mandate of the people wants to show a good signal to the community (Trisnawati and Achmad, 2014). This signal can be in the form of presenting accurate financial reports, delivering information on government performance, improving public services, and packaging financial performance and achievement that is simple and attractive to read by users. The internet is the most effective medium that can be used to show these positive signals to the public (Puspita and Martani, 2012).

In practice, not all local governments have active official websites that are maintained either in terms of content or the latest news, even though regulations are governing local government websites. Also, not all local governments that have official websites have 
published financial reports on their respective websites. This is supported by the findings of Trisnawati and Achmad (2014) which show that not all local governments publish complete financial reports each year, causing differences in the quality and financial information between local governments. Research in several countries has shown that one form of transparency and accountability of local government can be done by publishing financial reports on the internet (Laswad et al., 2005). In Indonesia, almost all LGs have official websites, but with different quality and roles. This is because the disclosure of information on the official local government website is still voluntary. It is the urgency of each local government that motivates local governments to voluntarily report government information on the official website.

DPRD as people's representatives has a supervisory function, namely controlling the running of the government so that it is always under the aspirations of the community and supervising the implementation and reporting of local government financial information to create a transparent and accountable local government atmosphere. A large number of DPRD members are expected to increase supervision of the Regional Government so that it has an impact on the increase in the disclosure of regional government financial reports. Several studies have also proven that oversight from the legislature, namely the DPRD, affects the level of disclosure of financial statements on the local government website.

The results of audits by the Supreme Audit Agency (BPK) can also affect the level of disclosure of internet financial reports. The BPK is tasked with conducting audits of state finances by examining finances, performance, and other audits for specific purposes. One of the results of the BPK audit or audit is a finding. BPK audit findings are cases found by BPK against regional government financial reports for violations committed by a region against internal control provisions as well as against applicable legislation.

Apart from legislative oversight and BPK audit results, the management of State finances requires competent state apparatus. A competent apparatus can support the success of the administration of the State in an orderly manner, obeying laws and regulations, efficiently, economically, effectively, transparently, and responsibly by paying attention to a sense of justice and compliance. To achieve this, it is not enough only with oversight by the legislature but also requires a strong internal control system.

In Indonesia, they have different total liabilities, but most of them, namely 80.91 percent, have total liabilities ranging from IDR $1,000,000,000$ to IDR $100,000,000,000$. The largest total liabilities are held by the three (3) district/city governments with a value of more than IDR $800,000,000,000$. Leverage is the ratio of total liabilities to total assets owned by local governments. Leverage describes the government's ability to guarantee the funds it borrows in providing services and programs for the community both now and in the future (Nosihana and Yaya, 2016). The smaller the leverage, the greater the government's ability to finance government operations with internal funds. The better the government's ability to finance government operations with internal funds is a positive signal that can be given to the public so that it can boost the level of financial information disclosure.

Local Own Revenue (PAD) is one of the important points that can be used to measure the financial performance of local governments. By comparing the total PAD with total regional revenue it will be known the level of regional independence. Meanwhile, the level of effectiveness of regional finances can be measured by comparing the target and the realization of PAD. Table 1.4 shows that 57.68 percent of district / city governments in Indonesia only have PAD of less than IDR 150,000,000,000, - while 2.56 percent have PAD of up to IDR 1,350,000,000,000. Differences in local government PAD will also cause differences in the financial performance of local governments. This difference in financial performance can be a factor affecting the level of disclosure of local government financial information on its official website.

\section{METHODS OF RESEARCH}

This type of research is quantitative research. Quantitative research is research that emphasizes theory testing through measuring research variables with numbers and 
analyzing data using statistical procedures (Indriantoro and Supomo, 2014: 12). Based on the objectives, this study is explanatory. Explanatory research or explanatory research is research that aims to test the hypothesis which states a causal relationship between two or more variables (Sukandarrumidi, 2006: 105). This study seeks to explain the causal relationship between variables to determine whether there is a relationship between leverage, legislative oversight, and local government performance, on audit findings and the level of government reporting in Indonesia.

Descriptive statistics provide an overview or description of data seen from the mean, standard deviation, variant, maximum, minimum, sum, range, kurtosis, and skewness (Ghozali, 2005: 19). The initial step of the analysis begins by identifying the distribution tendency of each variable. Descriptive statistical analysis was used to see the trend of each research variable. Model conceptualization is the first step in PLS-SEM analysis. At this stage, the researcher must develop and measure the construct (Ghozali and Latan, 2015: 48). Modeling in PLS-SEM consists of two sub-models, namely: the measurement model or the outer model and the structural model or the inner model. The outer model or measurement model shows how to manifest or observable variables represent latent variables to be measured (Ghozali and Latan, 2015: 7). The measurement model in this study uses an outer formative model.

After passing the conceptualization stage of the model, the next step is to determine what algorithm analysis method will be used for model estimation. The SmartPLS 3.0 program provides three choices of algorithm analysis methods, namely factorial, centroid, and path or structural weighting (Ghozali and Latan, 2015: 51). This study uses a path scheme or structural weighting. Ghozali and Latan (2015: 52) state that in general there are two methods used by researchers in the SEM field to carry out the resampling process, namely bootstrapping and jackknifing. The bootstrapping method uses all of the original samples to resample them. Meanwhile, the jackknifing method only uses a subsample of the original sample which is grouped into groups to re-sample. In this study, the bootstrapping method is used.

The next step is to draw a path diagram of the model to be estimated. The path diagram in this study can be described as follows:

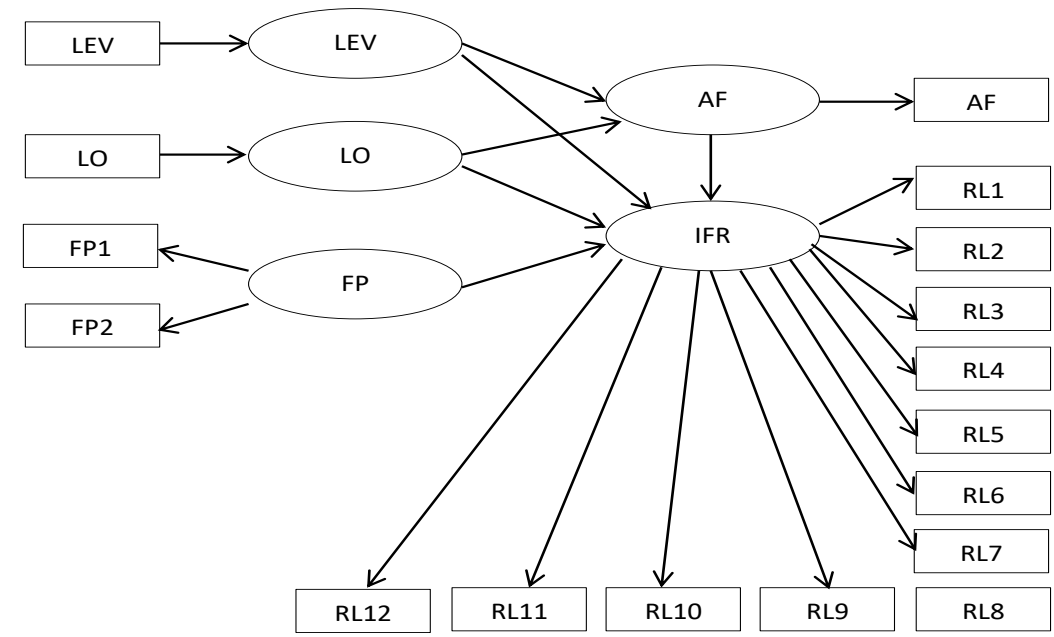

Figure 1 - Structural Model and Measurement

The equation of the Outer Model Formative measurement (outer model):

$\mathrm{LEG}=\lambda 1 \mathrm{LEG} 1+\delta 1$

$\mathrm{PL}=\lambda 1 \mathrm{PL} 1+\delta 2$

$\mathrm{KK}=\lambda 1 \mathrm{KK} 1+\lambda 2 \mathrm{KK} 2+\delta 3$

$\mathrm{TA}=\lambda 1 \mathrm{TA} 1+\varepsilon 1$

$\mathrm{IFR}=\lambda 1 \mathrm{IFR} 1+\lambda 2 \mathrm{IFR} 2+\lambda 3 \mathrm{IFR} 3+\lambda 4 \mathrm{IFR} 4+\lambda 5 \mathrm{IFR} 5+\lambda 6 \mathrm{IFR} 6+\lambda 7 \mathrm{IFR} 7+\lambda 8 \mathrm{IFR} 8+\lambda 9 \mathrm{IFR} 9+\lambda 10 \mathrm{IFR} 10+$ $\lambda 11 \mathrm{IFR} 11+\lambda 12 \mathrm{IFR} 12+\varepsilon 2$ 
The inner model test is carried out by looking at the significant value to see the effect between variables wherein SEM which is more often used is the bootstrapping method (Ghozali and Latan, 2015: 80). For the significant value of hypothesis support, a comparison of the T-table and T-Statistics values can be used in the estimation results for path coefficient (path coefficient value). If T-statistics is greater than T-table, it means that the hypothesis is supported. The significant value used for the one-tailed hypothesis with a confidence level of 95 percent (alpha 5 percent) is 1.66 and the two-tailed hypothesis with a confidence level of 95 percent (alpha 5 percent) is 1.96 .

Testing the moderating effect in PLS is used to show the interaction between exogenous variables (predictors) and moderating variables in influencing endogenous variables (Ghozali and Latan, 2015: 163). In testing the moderation effect, the output of the significance test parameter is seen in the total effect table to see the total effect of predictions (direct and indirect effect). This is because the moderation effect is not only tested for the direct effect but also the interaction relationship between exogenous variables and moderating variables on endogenous variables (indirect effect).

\section{RESULTS OF STUDY}

Evaluation of the measurement model (outer model) serves to test the validity and reliability of the model. The outer model in this study was evaluated through convergent validity and discriminant validity of construct-forming indicators and composite reliability and Cronbach alpha for the indicator block. Convergent validity relates to the principle that the measures (manifest variables) of a construct should be highly correlated. This test is seen from the loading factor value for each construct indicator. The loading factor value range of 0.5 to 0.6 is considered sufficient. PLS Algorithm obtained the following preliminary results of the research model:

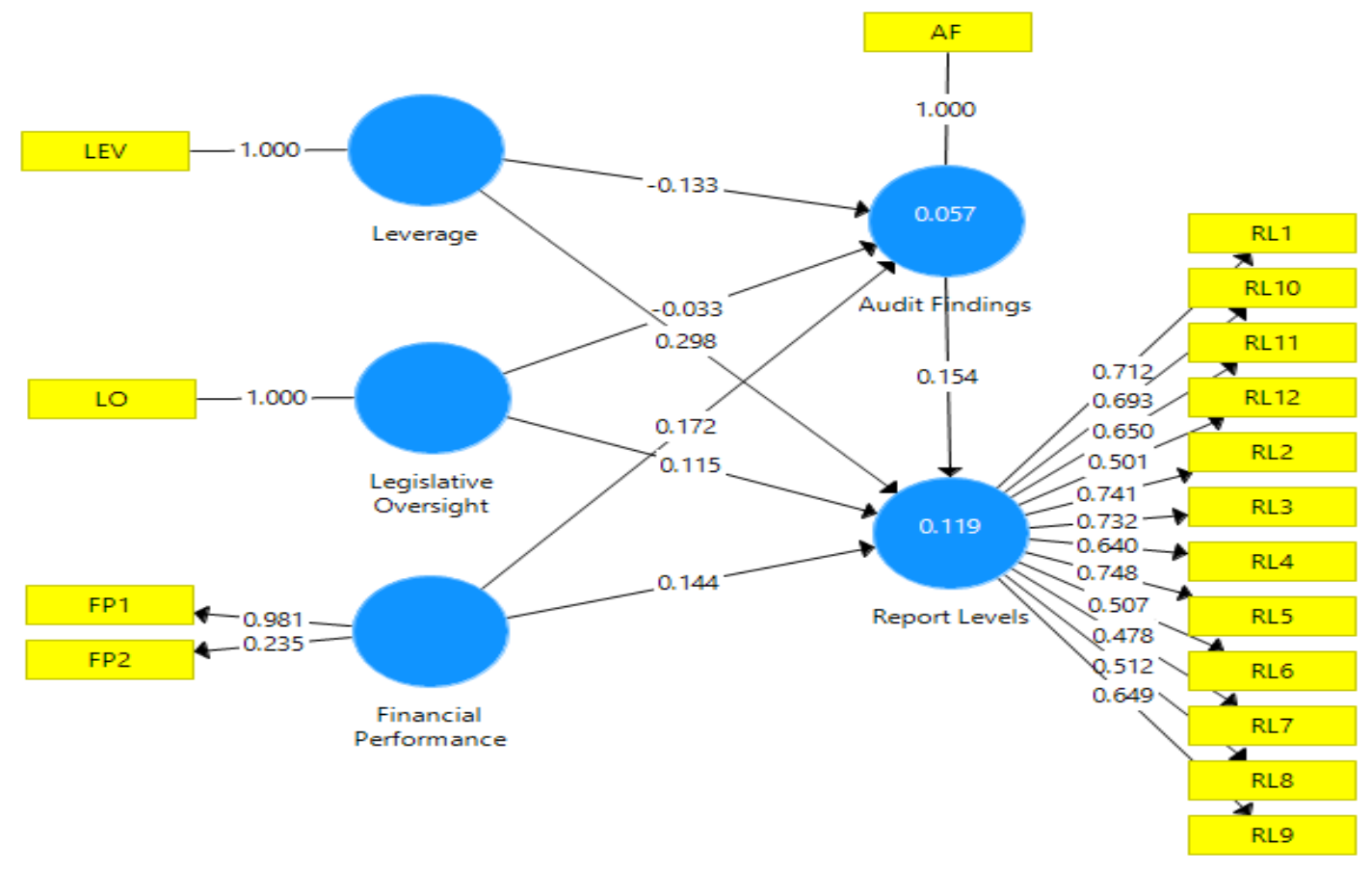

Figure 2 - Initial PLS Algorithm Results

The results of the analysis above indicate that the loading factor value of the FP1 indicator on the financial performance construct has a value greater than 0.6 , namely 0.981 . This means that the FP1 indicator can measure the financial performance construct in this study. Conversely, the loading factor value of the FP2 indicator does not meet the validity requirements of the financial performance construct because it has a value smaller than 0.6 , namely 0.235 . This indicates that the FP2 indicator does not correlate with the financial 
performance construct so that this indicator is dropped from the model. Likewise, the indicator values $R L 12$, RL6, RL7, RL8 do not meet the validity requirements because the value is less than 0.6 .

Table 1 - R-square value

\begin{tabular}{|l|l|}
\hline $\mathrm{n} / \mathrm{n}$ & $\mathrm{R}$-square \\
\hline Audit Findings & 0,057 \\
\hline Report Levels & 0,119 \\
\hline
\end{tabular}

Source: Processed Data, 2021.

Based on Table 1, it can be seen that the R-square value of the relationship between leverage variables, legislative oversight, and financial performance on audit findings is 0.210 . The R-square value of 0.057 or 5.7 percent is classified as a weak influence model. This shows that the construct of audit findings can be explained by the variables of leverage, legislative oversight, and financial performance by only 5.7 percent. The remaining 94.3 percent is explained by other variables outside the model built in this study. For the variable leverage, legislative oversight, and financial performance on the report level is 0.119 , the Rsquare value of 0.119 or 11.9 percent is classified as a weak influence model. This shows that the construct of the report level can be explained by the variables of leverage, legislative oversight, and financial performance by only 11.9 percent. The remaining 89.1 percent is explained by other variables outside the model built in this study.

Table 2 - Results of Path Coefficient Analysis

\begin{tabular}{|l|l|l|l|}
\hline $\mathrm{n} / \mathrm{n}$ & Original Sample (O) & T Statistics (| O/STDEV |) & P Values \\
\hline Audit Findings -> Report Levels & 0,154 & 2,152 & 0,032 \\
\hline Financial Performance -> Audit Findings & 0,172 & 1,996 & 0,046 \\
\hline Financial Performance -> Report Levels & 0,144 & 1,226 & 0,221 \\
\hline Legislative Oversight -> Audit Findings & $-0,033$ & 0,504 & 0,614 \\
\hline Legislative Oversight -> Report Levels & 0,115 & 2,521 & 0,012 \\
\hline Leverage -> Audit Findings & $-0,133$ & 0,896 & 0,371 \\
\hline Leverage -> Report Levels & 0,298 & 2,408 & 0,016 \\
\hline
\end{tabular}

Source: Processed Data, 2021.

The first hypothesis states that the better the audit findings, the better the level of reporting to local governments in Indonesia. Table 1 shows that the t-statistic value for the effect of audit findings on the level of local government reports is 2.152 , this value is greater than the t-table value at the 5 percent significance level, namely 1.65, so it can be concluded that the hypothesis is accepted. The p-value for the effect of audit findings on the report level is 0.032 smaller than the alpha value of 0.05 . This means that the relationship between the audit findings and the report level is significant so that the hypothesis is accepted. The second hypothesis states that the better the financial performance, the better the audit findings in the Indonesian local government, the t-statistic value for the effect of financial performance on the level of audit findings is 1.996 this value is greater than 1.65, as well as the P-value of 0.046 , is smaller of 0.05 so it can be concluded that financial performance has a significant impact on the audit findings. The third hypothesis states that financial performance has no impact on the report level, the t-statistic value for the effect of financial performance on the report level is 1.226 and for the P-value of 0.221 is greater than 0.05 , this indicates that financial performance does not have a significant impact on the level of report local government in Indonesia. The fourth hypothesis states that legislative oversight has no impact on audit findings. The statistical value on the t-count of 0.504 is smaller than 1.65 as well as the P-value of 0.614 which is greater than 0.05 , this indicates that legislative oversight does not have a significant impact on the level of local government reports in Indonesia. The fifth hypothesis states that the better the level of legislative oversight, the better the report level of regional government. The statistical value for the t-count of 2.521 is greater than 1.65 as well as the P-value of 0.012 which is smaller than 0.05 , this indicates that legislative oversight has an effect and is significant on the level of local government 
reporting in Indonesia. The sixth hypothesis states that leverage has no impact on audit findings. The result of the t-count statistical value of 0.896 is smaller than 1.66 as well as the $P$-value of 0.371 which is greater than 0.05 , this indicates that leverage has no and insignificant effect on audit findings in local governments in Indonesia. The seventh hypothesis states that the greater the level of government leverage, the better the report rate. At the t-count value of 2.408 which is greater than 1.66 as well as the P-value of 0.016 which is smaller than 0.05 , it can be concluded that leverage has a significant impact on the level of local government reports in Indonesia.

Table 3 - Indirect Effects

\begin{tabular}{|l|l|l|l|}
\hline & Original Sample (O) & T Statistics (| O/STDEV |) & P Values \\
\hline Financial Performance -> Audit Findings - Report Levels & 0,026 & 1,527 & 0,127 \\
\hline Legislative Oversight -> Audit Findings - Report Levels & $-0,005$ & 0,477 & 0,634 \\
\hline Leverage -> Audit Findings -> Report Levels & $-0,020$ & 0,666 & 0,506 \\
\hline
\end{tabular}

Source: Processed Data, 2021.

The indirect effect of financial performance on the level of the report through the mediation variable of audit findings shows a value of 0.026 with an at-count of 1.527 below 1.65 and a $P$ value of 0.127 , meaning that financial performance does not indirectly affect the level of the report through the audit findings variable. The indirect effect of legislative oversight on the report level through the mediation variable of audit findings shows a value of -0.005 with an at-count of 0.477 below 1.65 and a $P$ value of 0.634 , meaning that legislative supervision indirectly does not affect the report level through the audit findings variable. The indirect effect of leverage on the report level through the mediation variable of audit findings shows a value of -0.020 with an at-count of 0.667 below 1.65 and a $P$ value of 0.506 , meaning that leverage indirectly does not affect the report level through the audit findings variable.

\section{DISCUSSION OF RESULTS}

The results of the measurement model (outer model), as previously described, show that all variable indicators are valid indicators that reflect the research variable loading above 0.6 except for the financial performance variable on the invalid effectiveness ratio indicator, the loading is below 0.6. also with the report level variables on the indicators $R L 12, R L 6$, $R L 7$, and RL8 indicated by the outer value. The results of the analysis have also shown the strongest indicators that reflect each of the research variables.

The results of the research on the first hypothesis indicate that the audit findings have an effect and are signed on the level of reporting of local governments in Indonesia. This research is in line with the signaling theory which explains that local governments will send various signals to the public as a basis for assessing whether the mandate given to the government has been carried out in earnest. A good audit finding shows that the local government has carried out the mandate of the community well, namely by presenting fair financial reports. The audit findings have a strong impact on creating government-level reports, if the audit findings are following what is expected by the local government, it will increase the disclosure of various supporting documents carried out following the instructions of the minister in the State.

Research on the second hypothesis states that financial performance has a significant influence on the level of local government reports. This research is in line with the concept of signaling theory in which local governments with good financial performance tend to conduct audit findings. The results of this study also support the stewardship theory. Local governments are more focused on organizational goals, namely providing services to the community, in this case fulfilling the need for financial information. The financial performance of local governments can be seen by the existence of good audit findings, in carrying out local government financial audits what needs to be done is to look at the financial statements 
that are made to be following applicable accounting standards, so good audit findings will lead to good financial performance as well.

The third hypothesis states that financial performance has no and significant effect on the level of local government reports. This research is not in line with the signaling theory which illustrates that the government will try to provide positive signals to the public regarding government performance as a form of government accountability. This positive signal can be in the form of disclosure of financial information which is presented in full through the official website of the local government. Good audit findings are obtained from good government performance and are an illustration of orderly regional financial management by the government. Therefore, a fair audit opinion can strengthen the effect of financial performance by reporting levels on local governments. However, the results of this study found the opposite result where the audit findings did not significantly correlate with financial performance and report rates.

The fourth hypothesis states that legislative oversight has no significant effect on audit findings. A large number of DPRD members is expected to increase supervision and reduce the possibility of agency problems between the government as the agent given the mandate by the community as the principal to carry out government duties so that a large number of DPRD members has an impact on an increase in the existence of reasonable audit findings without government exception. Regions in this study legislative oversight did not have a positive impact on audit findings. Legislative members in Indonesia still do not reflect the level of tight supervision in the local government so that in practice there are still many regional governments that still find confusion in disclosing their financial reports.

The fifth hypothesis states that legislative oversight has a significant and significant effect on the level of government reports. The local government acts as an agent who is authorized by the community in implementing governance and has the information the community needs. The community is the principal who gives the mandate and also as the owner of resources who have interests and need information. However, often government implementation only focuses on the interests of the government apparatus itself so that the objectives of implementing government are not achieved. Therefore, the legislative institution of the Regional People's Representative Council or what is known as the DPRD as the legislative body has a supervisory function, namely controlling the running of the government so that it is always following the aspirations of the community and supervising the implementation and reporting of local government financial information to create an atmosphere of transparent and transparent local government. accountable, so that in this study the better the legislative oversight will cause the level of government reports to be better too, but the implementation of audits in local governments cannot mediate the level of government reports.

The sixth hypothesis states that leverage has no and significant effect on audit findings. Leverage in this study is measured by comparing total liabilities to total assets owned by local governments. High leverage will require the government to provide monitoring media for creditors to monitor the use of borrowed funds and monitor the government's ability to pay off debts. Even though the leverage of local governments has increased it has no impact on the audit findings.

The seventh hypothesis states that leverage has a positive and significant effect on the level of government reports. Leverage shows the ability of local governments to guarantee borrowed funds using the total assets owned by the local government. The report level is an effective means of assisting local governments in providing information related to the use of funds and the ability of local governments to return borrowed funds to creditors, however, leverage cannot be mediated by audit findings against the report level. The concept of signaling theory, local governments will provide signals related to their ability to return borrowed funds by disclosing financial information through local government websites. Financial information published must have good quality as evidenced by obtaining an unqualified opinion from the BPK. However, the results of this study are not in line with the concept of signaling theory. Local governments that have high leverage do not publish financial information on their official website. This is because local governments with high 
leverage are considered to have poor performance so that local governments tend not to disclose financial information so as not to become the spotlight of creditors. In other words, local governments are not yet fully open to external parties such as creditors. This is in contrast to the concept of stewardship theory. The local government as steward should be more open to the community because the main objective of the government is service to the community. The public needs financial information to assess government performance.

\section{CONCLUSION}

The audit findings have an effect and are signed on the level of local government reporting in Indonesia or the audit findings have a positive impact on increasing financial disclosure in local governments. Financial performance has a significant and significant effect on audit findings or the better the financial performance of local governments will lead to better audit findings. Financial performance does not affect and is significant on the level of local government reporting in Indonesia, meaning that even though the financial performance is very good, it will not lead to high financial openness. Legislative oversight does not affect and is significant on audit findings in local governments, meaning that legislative oversight does not have a positive impact on audit findings. Legislative observers have a significant and significant influence on the level of local government reporting in Indonesia or the high level of legislative oversight will lead to a better level of government reporting. Leverage has no effect and is significant on audit findings; high leverage has no impact on good audit findings. Leverage has a significant and significant effect on the level of government reports, meaning that the higher the local government debt, the better the financial disclosure.

\section{REFERENCES}

1. Adiputra, A. I. M. P., Utama, S., \& Rossieta, H. (2018). Transparency of Local Government in Indonesia. Asian Journal of Accounting Research, 3(1), 123-138. https://doi.org/10.1108/AJAR-07-2018-0019.

2. Agranoff, R. (2014). Local Governments in Multilevel Systems: Emergent Public Administration Challenges. The American Review of Public Administration, 44(4_suppl), 47S-62S. https://doi.org/10.1177/0275074013497629.

3. Ahrens, T., \& Ferry, L. (2015). Newcastle City Council and the Grassroots: Accountability and Budgeting under Austerity. Accounting, Auditing \& Accountability Journal, 28(6), 909933. https://doi.org/10.1108/AAAJ-03-2014-1658.

4. Alshumrani, S., Munir, R., \& Baird, K. (2018). Organisational Culture and Strategic Change in Australian Local Governments. Local Government Studies, 44(5), 601-623. https://doi.org/10.1080/03003930.2018.1481398.

5. Ammons, D. N., Liston, E. G., \& Jones, J. A. (2013). Performance Management Purpose, Executive Engagement, and Reported Benefits among Leading Local Governments. State and Local Government Review, 45(3), 172-179. https://doi.org/10.1177/0160323X13498261.

6. Bach, S., \& Stroleny, A. (2014). Restructuring UK Local Government Employment Relations: Pay Determination and Employee Participation in Tough Times. Transfer: European Review of Labour and Research, 20(3), 343-356. https://doi.org/10.1177/1024258914535546.

7. Batara, E., Nurmandi, A., Warsito, T., \& Pribadi, U. (2017). Are Government Employees Adopting Local E-Government Transformation? The Need for Having the Right Attitude, Facilitating Conditions and Performance Expectations. Transforming Government: People, Process and Policy, 11(4), 612-638. https://doi.org/10.1108/TG-09-2017-0056.

8. Barut, M., Raar, J., \& Azim, M. I. (2016). Biodiversity and Local Government: A Reporting and Accountability Perspective. Managerial Auditing Journal, 31(2), 197-227. https://doi.org/10.1108/MAJ-08-2014-1082. 
9. Boonperm, J., Haughton, J., \& Khandker, S. R. (2013). Does the Village Fund Matter in Thailand? Evaluating the Impact on Incomes and Spending. Journal of Asian Economics, 25, 3-16. https://doi.org/10.1016/j.asieco.2013.01.001.

10. Bordogna, L., \& Neri, S. (2014). Austerity Policies, Social Dialogue and Public Services in Italian Local Government. Transfer: European Review of Labour and Research, 20(3), 357-371. https://doi.org/10.1177/1024258914535548.

11. Botica-Redmayne, N., Dormer, R., \& Grossi, G. (2017). Local Government Accounting and Accountability - Challenges and Choices. Pacific Accounting Review, 29(4), 466468. https://doi.org/10.1108/PAR-10-2017-0078.

12. Cho, E., \& Kim, S. (2015). Cronbach's Coefficient Alpha: Well Known but Poorly Understood. Organizational Research Methods, 18(2), 207-230. https://doi.org/10.1177/1094428114555994.

13. Donaldson, L, and Davis, J. H. 1991. Stewardship Theory or Agency Theory: CEO Governance and Shareholder Returns. Australian Journal of Management, 16: 49-64

14. Ehalaiye, D., Botica-Redmayne, N., \& Laswad, F. (2017). Financial Determinants of Local Government Debt in New Zealand. Pacific Accounting Review, 29(4), 512-533. https://doi.org/10.1108/PAR-11-2016-0104.

15. Gooden, S. T., \& Rissler, G. E. (2017). Local Government: Social Equity "First Responders." State and Local Government Review, 49(1), 37-47. https://doi.org/10.1177/0160323X17720268.

16. Goodman, D., French, P. E., \& Battaglio, R. P. (2015). Determinants of Local Government Workforce Planning. The American Review of Public Administration, 45(2), 135-152. https://doi.org/10.1177/0275074013486179.

17. Ghozali, Imam and Hengky Latan. 2015. Partial Least Square: Konsep, Teknik and Aplikasi Menggunakan Program SmartPLS 3.0. Semarang: Badan Penerbit Universitas Diponegoro.

18. Grover, C. (2014). From the Social Fund to Local Welfare Assistance: Central-Local Government Relations and 'Special Expenses.' Public Policy and Administration, 29(4), 313-330. https://doi.org/10.1177/0952076714529140.

19. Guga, E. (2018). Local Government Modernization in Albania: Historical Background and the Territorial Reform 2015-2020. International Journal of Public Sector Management, 31(4), 466-506. https://doi.org/10.1108/lJPSM-01-2017-0018.

20. Gupta, B., \& Mukhopadhyay, A. (2016). Local Funds and Political Competition: Evidence from the National Rural Employment Guarantee Scheme in India. European Journal of Political Economy, 41, 14-30. https://doi.org/10.1016/j.ejpoleco.2015.10.009.

21. Haughton, J., Khandker, S. R., \& Rukumnuaykit, P. (2014), Appraising the Thailand Village Fund. Asian Economic Journal, 28(4), 363-388.

22. Hay, R., \& Martin, S. (2014). Controlling Local Government Spending: The Implementation and Impact of Capping Council Taxes. Local Government Studies, 40(2), 224-239. https://doi.org/10.1080/03003930.2013.795890.

23. Heinelt, H., \& Stolzenberg, P. (2014). 'The Rhinish Greeks'. Bailout Funds for Local Government in the German Federal States. Urban Research \& Practice, 7(2), 228-240. https://doi.org/10.1080/17535069.2014.910934.

24. Indriantoro, Nur and Bambang Supomo. 2014. Metode Penelitian Bisnis Untuk Akuntansi \& Manajemen. Cetakan Keenam. Yogyakarta:BPFE.

25. Instruksi Mendagri No. 188.52/1797/SJ Tahun 2012 tentang Transparansi Pengelolaan Anggaran Daerah.

26. Jensen, Michael C., and William H.Meckling. 1976. Theory of The Firm: Managerial Behavior, Agency Cost and Ownership Structure. Journal of Financial Economics, 3 (4): 305-360, Oktober 1976.

27. Jurnali, T., \& Siti-Nabiha, A. K. (2015). Performance Management System for Local Government: The Indonesian Experience. Global Business Review, 16(3), 351-363. https://doi.org/10.1177/0972150915569923.

28. Kajimbwa, M. G. A. (2018). Benchmarking Accountability of Local Government Authorities in Public Procurement in Tanzania: A Methodological Approach. 
Benchmarking: An International Journal, 25(6), 1829-1843. https://doi.org/10.1108/BIJ08-2016-0120.

29. Khongsatjaviwat, D., \& Routray, J. K. (2015). Local Government for Rural Development in Thailand. International Journal of Rural Management, 11(1), 3-24. https://doi.org/10.1177/0973005215569383.

30. Laswad, Fawzi, Fisher, Richard \& Oyelere, Peter, 2005. Determinants of Voluntary Internet Financial Reporting by Local Government Authorities. Journal of Accounting and Public Policy.

31. Mookherjee, D. (2014). Accountability of Local and State Governments in India: An Overview of Recent Research. Indian Growth and Development Review, 7(1), 12-41.

32. Porumbescu, G. A. (2015). Using Transparency to Enhance Responsiveness and Trust in Local Government: Can It Work? State and Local Government Review, 47(3), 205213. https://doi.org/10.1177/0160323X15599427.

33. Pugalis, L., \& Bentley, G. (2013). Storming or Performing? Local Enterprise Partnerships Two Years On. Local Economy, 28(7-8), 863-874.

34. Puspita, Rora and Dwi Martani. 2012. Analisis Pengaruh Kinerja and Karakteristik Pemda Terhadap Tingkat Pengungkapan and Kualitas Informasi dalam Website Pemda. Simposium Nasional Akuntansi XV. Banjarmasin.

35. Putubasai, E. (2018). Analysis of Community and Village Government Participation in Village Fund Management. Samurai International Journal of Social Sciences and Development, 2(1), 32-38. https://doi.org/10.24967/saburaiijssd.v2i1.329.

36. Ramly, A., Wahyuddin, W., Mursyida, J., \& Mawardati, M. (2018). The Implementation of Village Fund Policy in Improving Economy of Village Society. Jurnal IImiah Peuradeun, 6(3), 459-478. https://doi.org/10.26811/peuradeun.v6i3.184.

37. Robbins, Walter A., and Austin, Kenneth R. 1984. Disclosure Quality in Governmental Financial Reports: An Assessment of the Appropriateness of a Compound Measure. Journal of Accounting Research, 24 (2): 412-421.

38. Rosa, C. P., \& Morote, R. P. (2016). The Audit Report as an Instrument for Accountability in Local Governments: A Proposal for Spanish Municipalities. International Review of Administrative Sciences, 82(3), 536-558. https://doi.org/10.1177/0020852314566000

39. Roskruge, M., Grimes, A., McCann, P., \& Poot, J. (2013). Homeownership, Social Capital and Satisfaction with Local Government. Urban Studies, 50(12), 2517-2534.

40. Rudiana. (2018). Governance Development Based on Village Fund Year 2016 in Bandung Regency: Portrait of Unconstrained Village in the Establishment of Development Priorities (Study in Ciburial Village Cimenyan District Bandung Regency). Advances in Social Sciences Research Journal, 5(3), 333-341.

41. Saliterer, I., \& Korac, S. (2014). The Discretionary Use of Performance Information by Different Local Government Actors - Analysing and Comparing the Predictive Power of Three-Factor Sets. International Review of Administrative Sciences, 80(3), 637-658.

42. Sandford, M. (2016). Public Services and Local Government: The End of the Principle of 'Funding Following Duties'. Local Government Studies, 42(4), 637-656. https://doi.org/10.1080/03003930.2016.1171753.

43. Sukan darrumidi. 2006. Metodologi Penelitian Petunjuk Praktis Untuk Peneliti Pemula. Yogyakarta: Gadjah Mada University Press.

44. Trisnawati, M,D., \& Achmad, K,. 2014. Determinan Publikasi Laporan Keuangan Pemda melalui Internet. Simposium Nasional Akuntansi XVII. Mataram. Lombok.

45. Wu, Y., \& Shi, Y. (2018). How Does Intergovernmental Fiscal Environment Affect General Fund Balances of Major American Cities? Local Government Studies, 44(6), 745-765, https://doi.org/10.1080/03003930.2018.1501365.

46. Zafra-Gómez, J. L., Bolívar, M. P. R., \& Muñoz, L. A. (2013). Contrasting New Public Management (NPM) Versus Post-NPM through Financial Performance: A CrossSectional Analysis of Spanish Local Governments. Administration \& Society, 45(6), 710 747. https://doi.org/10.1177/0095399711433696.

47. Zerbinati, S/ (2012) Multi-level Governance and EU Structural Funds: An Entrepreneurial Local Government Perspective. Local Government Studies, 38(5), 577-597. 